\title{
Detection of Anisakidae larvae in fish products commercial- ized in Sicily
}

Stefania Graci, Rosaria Collura, Maria Drussilla Buscemi, Antonella Costa, Gaetano Cammilleri, Valentina Cumbo, Giuseppe Giangrosso, Michele Chetta, Antonello Cicero, Antonio Vella, Andrea Macaluso \&Vincenzo Ferrantelli

Centro di Referenza Nazionale per le Anisakiasi, Istituto Zooprofilattico Sperimentale della Sicilia “A. Mirri”, Via G. Marinuzzi 3, Palermo, Italy

ABSTRACTS

In this work a total of 1331 fish samples belonging to 15 species (Engraulis encrasicolus, Alaccia aurita, Loligo vulgaris, Trigla lyra, Conger conger, Merluccius merluccius, Zeus faber, Lophius piscatorius, Sardina pilchardus, Lepidopus caudatus, Scorpaena scrofa, Scomber scombrus, Trachurus trachurus, Todarodes sagittatus, Trachinus draco) from Sicilian commercialized in Sicily (FAO 37, FAO 37.1.3, FAO 37.1.1, FAO 37.2.2, FAO 37.3, FAO27,FAO 41, FAO87), were examined for the detection of Anisakidae larvae and molecular identification. The fish samples were examined for the research of nematodes by visual inspection and digestion method according to the EC Regulation 2075/2005. Detected larvae were subjected to morphological identification through the optical microscopy. Subsequently, the DNA was extracted and the molecular identification of the larvae was conducted by RFLP-PCR of the nuclear ITS region (ITS-1, ITS-2 and 5.8 S subunit). The polymerase chain reactions targeting the cytochrome c oxidase subunit II (cox2) was performed and subjected to sequence reaction. A number of 370 larvae have been identified at species level, of which 330 belong to the Anisakis pegreffii, 23 to the Anisakis simplex sensu strictu, 6 to the recombinant genotype Anisakis pegreffii/simplex s. s., 1 to Anisakis physeteris and 10 to Hysterothylacium fabri. The data obtained provide interesting reflections on the presence of parasites belonging to the Anisakidae family in fishery products marketed in the Sicilian territory. These findings are an excellent tool for assessing and preventing possible risks due to the consumption of these products.

KEY WORDS Anisakis; nematodes; larvae; PCR.

Received 22.11.2019; accepted 10.12.2019; published online 20.12.2019

Proceedings of the 4th International Congress on Biodiversity "Man, Natural Habitats and Euro-Mediterranean Biodiversity", November 17th-19th, 2017 - Malta

\section{INTRODUCTION}

In 2002, the Parliament of the European Union have developed a revision on the Community legislation about the production, marketing and food control, aimed to increasing the level of safety of food products. The EC Regulation 2002/178 laying down the general principles and requirements of food law and constituting the European Food Safety Authority (EFSA). Subsequently, a group of regulations, commonly called "hygiene package" were established from 1 January 2006. These regulations have redefined the existing EU provisions on hygiene of production and food marketing and have 
set new rules on the food control for Competent $\mathrm{Au}$ thorities and food sector operators. In recent years in Italy, we have seen an increasing consumption of raw fish due by importation of exotic typical products such as sashimi and sushi, and the increased consumption of different Italy culinary preparations such as marinated anchovies or carpaccio.

The Regulation 853/2004 imposes the food sector operators to freeze fish products eaten raw, this procedure ensuring food security. In fact there is a risk of parasites presence in fish fillets that can lead to zoonotical pathologies if larvae are eaten alive. The BIOHAZ panel of the European Food Safety Authority (EFSA recommended member states to carry out coordinated studies aimed to increase knowledge about the zoonotic diseases linked to Anisakis (Scientific Opinion on risk assessment of parasites in fishery products and EFSA Panel on Biological Hazards (BIOHAZ)). The study aims to estimate the prevalence of infestation of Anisakidae nematodes in the fish products commercialized and bred in Sicily and estimate the geographical and seasonal distribution of Anisakidae infestation

\section{MATERIAL AND METHODS}

The fish samples were examined for the research of nematodes in the stomach, intestine, abdominal cavity and muscle by visual inspection and digestion method. Detected larvae are subjected to identification at genus level, through the optical microscopy (Leica DM 2000), according to morphological characters (Berland, 1961). Subsequently, the larvae were subjected to molecular analysis. Genomic DNA extraction were conducted by special kits based on the use of affinity columns, according to the manufacturer's instructions. Polymerase chain reactions targeting the complete ITS region ITS-1, 5.8S, ITS-2 and the cytochrome c oxidase subunit II $(\cos 2)$ were performed. Purification of ITS and cox 2 gene amplification products was carried out with Illustra GFX PCR DNA and Gel Band Purification kit following the manufacturer's instructions. The purified products were sent to Macrogen company (Amsterdam, Holland) for Sanger sequencing. The sequences were compared with previously characterised ITS and $\operatorname{cox} 2$ sequences of Raphidascarididae family published for identification by using the Basic Local Alignment

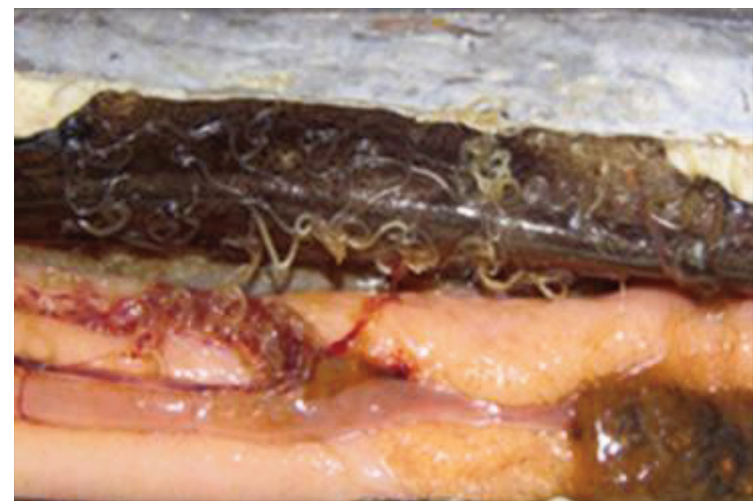

Figure 1. Anisakidae larvae infestation.

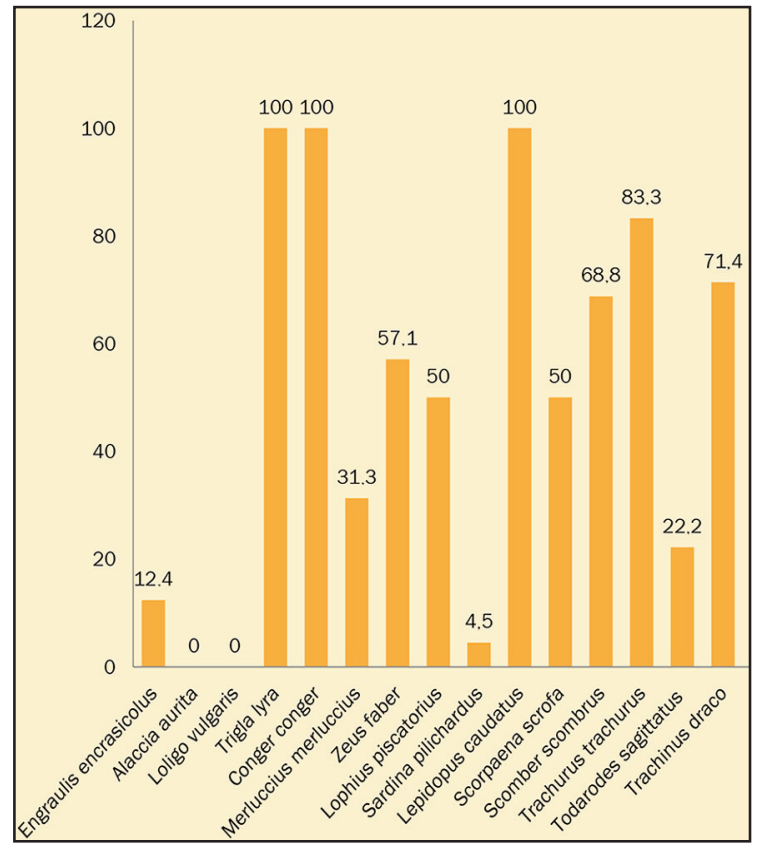

Figure 2. Infestation prevalence in the examined species.

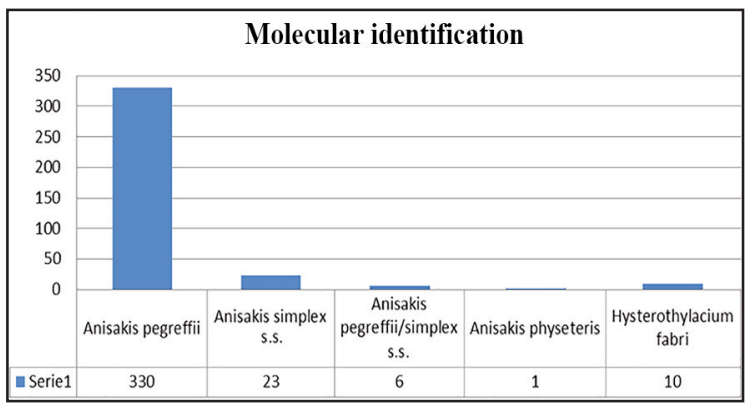

Figure 3. Molecular identificaton of Anisakidae larvae. 


\begin{tabular}{|c|c|c|c|c|c|c|c|c|c|}
\hline Species & $\begin{array}{c}\text { FAO } \\
37\end{array}$ & $\begin{array}{c}\text { FAO } \\
37.1 .3\end{array}$ & $\begin{array}{c}\text { FAO } \\
37.1 .1\end{array}$ & $\begin{array}{c}\text { FAO } \\
37.2 .2\end{array}$ & FAO 27 & $\begin{array}{l}\text { FAO } \\
37.3\end{array}$ & FAO 41 & FAO 87 & Total \\
\hline Alaccia aurita & 31 & & & & & & & & 31 \\
\hline $\begin{array}{c}\text { Engraulis } \\
\text { encrasicolus }\end{array}$ & 434 & 114 & 85 & & 75 & & & 88 & 796 \\
\hline Loligo vulgaris & & & & 10 & & & & & 10 \\
\hline Trigla lyra & & & & 5 & & & & & 5 \\
\hline Conger conger & & & & 8 & & & & & 8 \\
\hline $\begin{array}{l}\text { Merluccius } \\
\text { merluccius }\end{array}$ & 49 & 3 & 13 & 15 & & & & & 80 \\
\hline Zeus faber & & & & 7 & & & & & 7 \\
\hline $\begin{array}{c}\text { Lophius } \\
\text { piscatorius }\end{array}$ & 2 & & & 4 & & & & & 6 \\
\hline $\begin{array}{c}\text { Sardina } \\
\text { pilichardus }\end{array}$ & 106 & & 111 & 32 & 15 & & & & 264 \\
\hline $\begin{array}{l}\text { Lepidopus } \\
\text { caudatus }\end{array}$ & 3 & & 2 & 3 & & & & & 8 \\
\hline $\begin{array}{l}\text { Scorpaena } \\
\text { scrofa }\end{array}$ & 4 & & & 3 & & 1 & & & 8 \\
\hline $\begin{array}{l}\text { Scomber } \\
\text { scombrus }\end{array}$ & 11 & & 10 & 2 & 9 & & & & 32 \\
\hline $\begin{array}{l}\text { Trachurus } \\
\text { trachurus }\end{array}$ & 11 & & 26 & 5 & & & & & 42 \\
\hline $\begin{array}{l}\text { Todarodes } \\
\text { sagittatus }\end{array}$ & 11 & 4 & & 9 & & & 3 & & 27 \\
\hline $\begin{array}{l}\text { Trachinus } \\
\text { draco }\end{array}$ & 4 & & & 2 & & 1 & & & 7 \\
\hline \multicolumn{10}{|l|}{ Totale } \\
\hline
\end{tabular}

Table 1. Type and number of samples analysed.

Search Tool (BLAST) via GenBank ${ }^{\mathrm{TM}}$. Sequence Alignment was conducted using ClustalW 2.1 and MEGA 6.05 software. Evolutionary relationship among the Hysterothylacium haplotypes was analysed using Neighbor Joining (NJ) trees (Tamura et al., 2007). The evolutionary distances for $\mathrm{NJ}$ tree were computed using the Maximum Composite Likelihood method (Tamura et al., 2004).

\section{RESULTS AND DISCUSSION}

One thousand three hundred and thirty-one fish samples were examined for Anisakidae larvae detection by visual inspection (Table 1) The prevalence of infestation for each species examined were calculated (Fig. 1, 2). The collected larvae were examined for genre identification by optical microscopy, while the molecular identification was performed by RFLP-PCR (Fig. 3). The results ob- tained revealed the presence of Anisakidae larve in 450 fish samples. The comparison of the results obtained with Chaligianis have showed the lower values in the samples of Merluccius merluccius and Scomber scombrus, indicating a higher rate of infestation in fish species from the Greek coast. Molecular analysis confirm Anisakis pegreffii as the Anisakidae parasite most present in Mediterranean Sea (FAO zone 37-37.1-37.2-37.3) and also found in samples of Engraulis encrasicolus of from the North East Atlantic (FAO area 27) and in a sample of Todarodes sagittatus from the South Atlantic (FAO zone 41). Furthermore, the presence of Anisakis simplex sensu strictu has generally been identified in mackerel or in European anchovy from North-East Atlantic (FAO area 27) and only in one case in salted anchovies samples derived from the Mediterranean (FAO zone 37). The hybrid genotype (Anisakis pegreffii/Anisakis simplex s.s.) was found in samples from probable areas of sympathy (FAO $37.1 .3 ; 37.1 .1 ; 37.2)$ between the 
Anisakis pegreffii and the Anisakis simplex s. s., in samples of Trachurus trachurus, Scomber scombrus, Merluccius merluccius and Engraulis encrasicolus. The species Anisakis physeteris was found in a single sample of Conger conger caught in FAO 37.2. The Hysterothylacium fabri has been identified in demersal fish samples such as Conger conger, Lophius piscatorius, Trigla lyra, Trachinus draco, Merluccius merluccius from FAO 37.2 and FAO 37.1 and in one case in one mackerel from the FAO area 27.

The results provide an exhaustive evaluation on the presence of Anisakidae parasites in fish caught and commercialized in Sicily in order to have a risk assessment associated with the consumption of these products (see also D'Amelio et al., 2000; 2010; Evans et al., 2001; Abollo et al., 2003; Bernardi, 2009; EFSA, 2010; Buchmann \& Kania, 2012; Chaligiannis et al., 2012).

\section{REFERENCES}

Abollo E., Paggi L., Pascual S. \& D’Amelio S., 2003. Occurrence of recombinant genotypes of Anisakis simplex s.s. and Anisakis pegreffii (Nematoda: Anisakidae) in an area of sympatry. Infection, Genetics and Evolution, 3: 175-181

Berland B., 1961. Nematodes from some Norwegian marine fishes. Sarsia, 2: 1-503.

Bernardi C., 2009. Preliminary study on prevalence of larvae of Anisakidae family in European sea bass ( $D i$ centrarchus labrax). Food Control, 20: 433-434. https://doi.org/10.1016/j.foodcont.2008.07.001

Buchmann K. \& Kania P., 2012. Emerging Pseudoterranova decipiens (Krabbe, 1878) problems in Baltic cod, Gadus morhua, associated with grey seal colo- nization of spawning grounds. Journal of Fish Diseases, 35: 861-866. https://doi.org/10.1111/j.13652761.2012.01409.x

Chaligiannis I., Lalle M., Pozio E. \& Sotiraki S., 2012. Anisakidae infection in fish of the Aegean Sea. Veterinary Parasitology, 184: 362-366. https://doi.org/ 10.1016/j.vetpar.2011.09.007

D'Amelio S., Mathiopoulos K. D., Santos C. P., Pugachev O. N., Webb S. C., Picanço M. \& Paggi L., 2000. Genetic markers in ribosomal DNA for the identification of members of the genus Anisakis (Nematoda: Ascaridoidea) defined by polymerase-chainreaction-based restriction fragment length polymorphism. International Journal for Parasitology, 30: 223-226. https://doi.org/10.1016/s0020-7519 (99)00178-2

D’Amelio S., Busi M., Ingrosso S., Paggi L. \& Giuffra E., 2010. Anisakis. In: Liu D. (Ed. ), Molecular detection of foodborne pathogens, pp. 757-768.

EFSA, European Food Safety Authority, 2010. Scientific Opinion on risk assessment of parasites in fishery products and EFSA Panel on Biological Hazards (BIOHAZ). EFSA Journal, 8, 1543.

Evans D.W., Irwin S.W.B. \& Fitzpatrick S., 2001. The effect of digenean (Platyhelminthes) infections on heavy metal concentrations in Littorina littorea. Journal of the Marine Biological Association of the United Kingdom, 81: 349-350. https://doi.org/10. 1017/S0025315401003873

Tamura K., Nei M. \& Kumar S., 2004. Prospects for inferring very large phylogenies by using the Neighbor-Joining method. Proceedings of the National Academy of Sciences, 101: 11030-11035.

Tamura K., Dudley J., Nei M. \& Kumar S., 2007. MEGA4: Molecular Evolutionary Genetics Analysis (MEGA) software version 4.0. Molecular Biology and Evolution 24: 1596-1599. https://doi.org/10. 1093/molbev/msm092 